\title{
Religious Value in the Local Wisdom of Labuhan Kombang Mountain Ngliyep Beach Malang District
}

\author{
Fitria Shalza Rahmaniar', Suyitno ${ }^{2}$, Supana $^{3}$, and Kundharu Saddhono ${ }^{4}$ \\ \{shalzarahmaniar1994@gmail.com¹, yitsuyitno52@gmail.com², \\ supanakaprodi@yahoo.co.id ${ }^{3}$, \& kundharu.uns@gmail.com ${ }^{4}$ \} \\ 1,2,3,4 Javanese Language and Literature Education, Postgraduate of Universitas Sebelas Maret, \\ Indonesia
}

\begin{abstract}
Labuhan Kombang Mountain, Ngliyep Beach is one of the local wisdom in Indonesia. A procession anchored the offerings to the beach to pray for the blessings that had been received and also to be given health and safety. This study aims to determine the religious value in the tradition of "Labuhan Kombang Mountain" in Ngliyep Beach, Malang Regency. Religious values related to religion and belief. Religion is the key to history, we can only understand the soul of a society if we understand its religion, we will not understand the cultural results of society, unless we understand the belief or religion that inspired it. This study uses a descriptive qualitative approach with the ethnographic method, the data source is the Labuhan Kombang Mountain procession. Data was collected using observation and in-depth interviews with traditional stakeholders and labuh relatives to support data analysis. This study can provide knowledge about the existence of religious values during the procession of Labuhan Kombang Mountain Ngliyep Beach namely by the presence of prayers offered to ancestral spirits or pepunden to obtain guidance, as well as recitation of Islamic prayers offered to Allah SWT which was read at the event kenduri after Labuhan is carried out.
\end{abstract}

Keywords: local wisdom, religious value, labuhan Kombang mountain.

\section{INTRODUCTION}

Human life is characterized by the dynamics of meaning and signs. All humanity in the world truly realizes that all necessities of life originate from a culture that has a dependency between one another so as to create a hereditary story from an event of the past that produces a belief or myth that lives up to now [1]. Culture is born as a form of expression to the challenges of the environment that surround the community of culture owner. The culture is realized from the knowledge of the community to solve their daily problems, problems that arise in the community, and anticipatory attitudes towards problems that might arise [2].

The Javanese feel obliged to preserve the beauty of the world, both the physical environment and the spiritual environment. Physical environment in the form of tools, objects, or buildings that are visible to the eye, while the spiritual environment, namely: traditions, procedures, 
ideals, and cultural values contained in society. The actions of the Javanese in maintaining their environment are realized by rituals. Ritual is an activity carried out to remember God, obtain salvation, and maintain self-balance. Rituals and identities have a close relationship because through rituals, the ritual groups communicate and reflect their existence through various symbols, which are full of meaning and at the same time become markers of their identity [3].

Local wisdom is the values that apply in a society. These values are believed to be true and become a reference in the daily behavior of the local community. The values of local wisdom are seen as entities that greatly determine the human dignity in their community because they contain elements of intelligence, creativity and local knowledge from the elites (figures) and the community [4]. In this context, local wisdom can be integrated with the system; beliefs, life views, norms, social values (ethics), knowledge, and culture that are expressed in the application of traditions adopted by the people from generation to generation [5].

Local wisdom which until now is still held firmly by its adherents, one of which, is the tradition of larung (float) offerings or commonly referred to as "Labuhan Kombang Mountain" which is in Ngliyep Beach, Malang Regency. Labuhan is carried out once a year with a Javanese calendar calculation which falls on every 13 at night on months of Maulud. Labuhan has been carried out by residents since 1913 until now, the Labuhan ceremony is still being carried out because the community feels that there are noble meanings and values in it. Larung offerings are usually carried out by people who live on the coast. One effort to give thanks for the results of the corps obtained by coastal communities is by holding the tradition of sea alms [6].

Research on larung offerings has been studied by Suryanti entitled "Sea Alms Traditional Ceremony on Cilacap Beach." This traditional ceremony also contains cultural, social and economic meanings [7]. The Labuhan ceremony has the purpose of asking for the welfare of life in the world and the hereafter. The difference with the research that the authors did is that in this study we will discuss the values of local wisdom in the form of religious values found in the Labuhan Kombang Mountain ceremony at Ngliyep Beach, Malang Regency.

Indonesian society is a religious community. Therefore the lives of individuals, communities and nations are always based on religious teachings. Politically, state life is also based on values that originate from religion. Based on that consideration, the values of education in the culture and character of the nation must be based on values and rules that originate from religion [8].

Local wisdom in the community is a custom/tradition that has deep roots and influences the daily life of the local community. Islam with its teachings, there are rahmatan lil 'alamin and full of tolerance see tradition selectively. Traditions will always be preserved and maintained as long as they are in accordance with and not contrary to faith. Even the tradition/custom or what is known as the term ' $u r f$ can be one of the bases of legal making [9]. Research on religious values in local wisdom has been carried out by Saddhono with the title Islamic Religious Value in Traditional Ceremony of Begalan Banyumasan as Educational Character for Student at Senior High Schools in Central Java [10].

Culture-based values and local wisdom are examples of education that have high relevance for life development skills, based on empowering local skills and potential in each region. The Indonesian people should return to their identity through the reinterpretation and reconstruction of their noble cultural values [11]. On the basis of the above considerations, in this study we will discuss religious values in the local wisdom of Labuhan Kombang Mountain, Ngliyep Beach, Malang Regency. 


\section{METHOD}

Research on religious values in the local wisdom of the Labuuhan Kombang Mountain, Ngliyep beach, Malang Regency is an ethnographic study with a qualitative approach. Qualitative research is an inquiry process of understanding based on distinct methodological traditions of inquiry that explores a social or human problems, the researcher builds a complex, holistic picture, analysis words, report detailed views of informants and conducts the study in a natural setting [12]. Ethnographic methods attempt to describe a nation's culture / group in terms of interpretation of beliefs, behaviors, languages, norms, and espoused value systems. In addition, ethnography is a study to describe culture by studying and understanding life views and cultural patterns in detail through ways of thinking, speaking, and behaving by indigenous people in a period of time and space [13]. The ethnography is more specifically in the transformation of religious values as the local wisdom of the people of Kedungsalam Village, Malang Regency. The data source in this study is the Labuhan Kombang Mountain procession. Data was collected using observation and in-depth interviews with traditional stakeholders and labuh relatives to support data analysis.

\section{RESULT AND DISCUSSION}

Local wisdom is a local knowledge system that is owned by the community based on ancestral experiences and instructions from generation to generation, is flexible to overcome local situations and conditions summarized in verbal and non-verbal expressions to obtain peace in living together, humane and dignified [14]. In a thought, local wisdom will create valuable values and norms for the importance of living together [15].

Local wisdom is a truth that has become a tradition and is a sacred value from God that must be preserved. In line with the opinion of Gobyah (2003), that local wisdom/local genius is a truth that has been as a tradition or steady in an area. Local wisdom is the combination of the values of the holy words of God and the existing values. Local wisdom is formed as a culture superiority of the local community and geographic conditions in the broad sense. Local wisdom is a product of ancient culture that should continually hold onto life. Although local value contained in it is considered very universal [16].

Labuhan Kombang Mountain Ngliyep Beach is one of the local wisdoms that is still being carried out by the people of Kedungsalam village, Donomulyo District, Malang Regency. Every year at 13 Maulud in Javanese calendar, villages from inside and outside of the Kedungsalam village work together to prepare what is needed for the Labuhan ceremony. The people never leave the Labuhan Kombang Mountain tradition. The community believes that by carrying out the Labuhan ceremony, all requests that are expected to be fulfilled, such as health, sustenance and so forth.

One of the values contained in a local wisdom is religious value. Religion is the cultural face of a unique nation. Religion is the basis of belief, so its cultural aspects often float on it. This represents religion as a universal cultural phenomenon. Religion is a distinctive part of culture [17] Religious values related to religion and belief. Religion is the key to history, we can only understand the soul of a society if we understand its religion [18]. Semi also added that we would not understand the cultural results of society, unless we understood the beliefs or religions that inspired them.

One of the local cultures of Indonesian people which have religious values is Labuhan Kombang Mountain, Ngliyep Beach in Malang Regency. Preparations which are made at the ceremony of Labuhan are activities carried out by village officials / local officials, regardless 
of the activities of the Labuhan Ceremony and are generally related to the development of tourism, preparing shelter for ceremonies / spectators, preparing performances and so on.

The next activity is the activities carried out by the heirs / families of the descendants of Mbah Atun along with community members. The initial activities they did, noted the uborampe or offerings from labuh relatives who would sacrifice and type of animals. This activity they carried out a day before the ceremony, and lasted until the evening night.

The series of activities in Labuahn Kombang Mountain can be detailed as follows: 1) tirakatan night activities starting at 00.01 on 13 nights of Maulud until dawn, approximately at 04.30 by all participants of the Labuhan; 2 ) cooking the offerings is carried out at approximately 05.00 by men in the form of offerings to be anchored as well as offerings used for kenduri; 3 ) anchoring offerings activities to the beach.

When the anchoring activity, the traditional stakeholders as the ceremony leader, immediately burned incense and offered a prayer on behalf of the participants, which essentially begged Mbok Nyai Ratu Mas that the victims be accepted and they were given good and mercy fortune. The elders start anchoring the offerings into the sea, followed by other participants, especially those who are sacrificing. The event was closed with kenduri (selametan). Kenduri is held at Mbah Atun's heritage house and led by Mudin Kedungsalam village to recite prayers.

Therefore, the activity anchoring the offerings to Ngliyep Beach is finished. Closing Ceremony indicates that a series of Labuhan Traditional Ceremony activities have been completed. The ceremony is attended by all participants of the Labuhan Ceremony. From time to time because of the changing times, the implementation of Labuhan traditional ceremonies also change, the changes only concern the technical aspects of the implementation, while the meanings and objectives remain the same, namely as an expression of gratitude to the Almighty God for all the mercy given. Besides that, it is also a form of preservation of the tradition of offerings to Nyai Ratu Mas, the ruler of the South Sea which was deeply confiscated by the supporting community. In the development of this Labuhan tradition, the city and regional governments of Malang participated in the handling and development of the Labuhan tradition. Since 1979 the district government of Malang has participated in handling the holding of the traditional Labuhan Kombang Mountain ceremony.

Indonesian society is religious, so various aspects of life's behavior cannot be separated from religious values. Therefore, one characteristic of local genius is usually 'very much related to the belief system' [19]. Some elements that shape local culture and wisdom are: the first humans, second ideas that are of good value, third truths that have been tradition, and fourth are recognized by society. By using these four elements in understanding it, it can be understood that in local culture and wisdom, religious values are inseparable. Valuable ideas become truths that are tradition and acknowledged by the community are the basic principles of all religions, especially the Islamic religion [20].

In Labuhan Kombang Mountain, the community acknowledges that the activity of anchoring offerings is a good idea to eliminate a disease that afflicts villagers, the community believes that after doing Labuhan, the disease that befalls the residents will disappear. Labuhan is a truth that has become a tradition passed down in the Kedungsalam village community. Until now the Labuhan ceremony is still being carried out by community members. These various rituals are synonymous with kejawen mysticism, namely a series of mystical steps to make Javanese truly survive eternally. Endraswara said that kejawen mysticism can be referred as local wisdom [21]. Every community has local wisdom that is characteristic and core of life [22]

The Labuhan ceremony is inseparable from ritual activities and the beliefs of the community. This activity is very related to religion. The public knows exactly what is permissible and not, at the Labuhan Gunung Kombang ceremony the traditional leaders pray 
for safety and longevity, ask for the refusal to disappear the pain, the disappearance of various diseases, get a real guidance from ancestral spirits and pepunden. Prayer is done by silence in one breath in each heart that is addressed to God Almighty. In this activity there was a syncretism between the local wisdom of the community in the form of Labuhan ceremony with religion, especially Islam. Religion as a larger narrative can gradually slip into culture in a society that they have trusted and a syncretic process takes place.

In the implementation of Labuhan it was colored by reading verses from the Qur'an. The recitation of the Holy Qur'an is carried out during Kenduri. Kenduri was carried out at the custom stakeholders' house after the Larungan event was completed. This shows that the majority of the residents of Kedungsalam village are Muslim and only express their gratitude to Allah, SWT. Prayers that are stated during the kenduri after the labuhan, which are read by the Mudin Kedung Salam village are as follows:

Bismillahirrahmanirrahim, Allahhumma solli wasalim ala syayidina muhammad sayidil wal Akhirin rodiala syahdati rasullullah hi ajemain ama baktdu alhamdulilah hirobbil alamin. Hamdan syakirin, hamdan na'imin, hamdan yu'afi niamahu wayukafi mazidah. Yaa Rabbana lakal hamdu kamaa yambaghi liljalali wajhikal karimi wa'adzimi sulthonik.

O God our Lord, all praise be to You, keeper of the universe. Praise for the gifts and pleasures that you bestowed on us. All praise for your majesty, all praise for your glory and your power. Give blessings and greetings to our prophet Muhammad SAW and his followers to the end of time.

Hadiyatan Wasilatan WarohmatanWa Nazillatan Wa barokatan Syamillatan lilla hadrotika mina syafina nuroti.Allahumma inna nas'aluka salamatan fiddien, wa'afiyatan fil jasadi, waziyadatan fil ilmi, wabarokatan fir rizki, watawbatan qablal mawt, warahmatan indal mawt, wamaghfiratan ba'dal mawt. Allahumma hawwin 'alayna fi sakaratil mawt, wa najata minannari, wa afwa indal hisab.

O God our Lord, we ask for the salvation of religion, physical health, increased knowledge and blessings, can repent before dying, get mercy when die, and get forgiveness after death. O God, make it easy for us at the wave of the death sentence. Free us from your punishment and get forgiveness when we are taken away.

Innallaha wa malaikatahu yusholluna 'alan nabi. Ya ayyuhalladziina amanu shollu 'alaihi wa salamu taslima, walhamdulillahirobil alamin.

Surely Allah and His angels are berselawat (praising and praying) on the Prophet (Muhammad s.a.w). O those who believe berselawatlah on it and say salam with respect to him [Al-Ahzab: 56].

The prayers offered were praising Allah SWT, praising the prophet Muhammad SAW, praying for religious harmony, asking for health, knowledge and blessing, receiving mercy and forgiveness from Allah SWT during life in the world and in the hereafter.

Religious elements according to Koentjaraningrat consist of: a) Religious emotions are soul vibrations that have come upon a human in his life, even though the vibration lasts only a few seconds and then disappears. This attitude involves religious emotions and is afraid to mix in believing in the occult and the sacred. $b$. The system of belief in religion, can be in the form of human thoughts and ideas, which relate to human beliefs and conceptions of God's attributes, supernatural forms (cosmology), the occurrence of nature and the world (cosmology), the hereafter (syatologi), forms and characteristics magic power, ancestral spirits, natural spirits, gods, evil spirits, ghosts, and other spirits. In addition, the belief system also concerns the system of values and systems of religious norms, moral teachings, and other religious doctrinal teachings that govern human behavior. c. Religious ceremonies can be in the form of human activities or actions carrying out offerings to God, gods, ancestral spirits and other spirits in an 
effort to communicate with God or other inhabitants of the unseen world. This rite can be done repeatedly, every day, every season, or only occasionally. Based on the content of the program, the ritual usually consists of a combination of one or several actions, such as praying, prostrating, offering, sacrificing, eating together, dancing, singing, processing, artsy drama, fasting, meditating, and so on [23].

Based on what was stated by Koentjaraningrat Labuhan Kombang Mountain can be said to be part of a culture that is religious in nature because it is a symbol of the beliefs and concepts of the community about God which is held every year. It is an expression of gratitude for the Kedungsalam Village community to Allah SWT for the sustenance that has been received by the people of the community. Islam became the religion of the majority of the people of Kedungsalam Village, as evidenced by the reading of the Qur'anic verses during the kenduri event after the labuhan was held. People also still believe in the spirits of ancestors and pepunden who reside. This is also in line with what was revealed by Hartoyo that various rituals have symbols such as symbols of submission to Almighty Allah, symbolic of the realization of living in harmony and peace with fellow human beings, even for fellow creatures of the Almighty God. This is done by, such as preparing bancaan and various offerings, including those that are not served for humans [24].

In the implementation of Labuhan, there is a separation between the hope intended for God and the rulers of the South Sea. This shows the influence of Islam on the local traditions of the Kedungsalam villagers. Based on that, it can be seen that Labuhan Kombang Mountain, Ngliyep Beach contains religious values. This is in line with the opinion of Nuha Islam and culture are two different entities. But both of them can influence each other. Islam as a religion with a set of values has influenced the cultural patterns and traditions of its adherents. However, the sociocultural aspects of the local community were not eroded [25].

\section{CONCLUSION}

Local wisdom contained in a community is inseparable from the existence of values. One of them is religious value, religious values can be obtained in rituals or procedures in carrying out a tradition. One tradition that contains religious values is the tradition of Labuhan Kombang Mountain, Ngliyep Beach. Religious values can be found in the prayers offered by the traditional leaders during the larung procession at the beach and also the prayers in the Qur'an which are offered by the village mudin, the prayers are addressed to the Prophet Muhammad and also Allah SWT when kenduri event after the Labuh program is finished. Religious values also exist in the purpose of doing the Labuhan tradition. Labuhan is the way the Kedungsalam villagers express their gratitude for the sustenance that Allah SWT has given. Religion and culture are two different entities, but both can influence each other, in this case religion as a set of values that have influenced the patterns of culture and traditions of the people.

\section{REFERENCE}

[1] N. Cristantyawati and L. Walensa, "Budaya Unu Tanah Dan Budaya Lio Menyoal Narasi Mitos Tanah, Hermeneutika Alam, Dan Komunikasi Lintas Generasi," Kawistara, vol. 8, no. 1, pp. 61-74, 2018. DOI: 10.22146/kawistara.29751.

[2] J.T. Haryanto, "Nilai Kerukunan Pada Cerita Rakyat Dayuhan-Intingan Di Kabupaten Tapin Kalimantan Selatan The Value Of Harmony In Dayuhan-Intingan Folklore In The Tapin District, South Kalimantan, Indonesia," Jurnal SmaRT, vol. 4, no. 1, pp. 1-14. 2018, DOI: 10.18784/smart.v4i1.598.g315. 
[3] Y. Rumahuru, "Ritual Ma'atenu Sebagai Media Konstruksi Identitas Komunitas Muslim Hatuhaha Di Pelauw Maluku Tengah," Kawistara, vol. 2, no. 1, pp. 36-47, 2012. DOI: 10.22146/kawistara.3949.

[4] A, Riyadi, "Kearifan Lokal Tradisi Nyadran Lintas Agama Di Desa Kayen-Juwangi Kabupaten Boyolali," Jurnal SmaRT, vol. 3, no. 2, pp. 139-153, 2017. DOI: 10.18784/smart.v2i01.g215.

[5] Sahlan, "Kearifan Lokal Pada Kabanti Masyarakat Buton Dan Relevansinya Dengan Pendidikan Karakter," El-Harakah, vol. 14, no. 2, pp. 312-325, 2012. DOI: 10.18860/el.v14i2.2311.

[6] Wahyudi,"Sedekah Laut" Tradition for in The Fishermen Community in Pekalongan, Central Java," Journal of Coastal Development, vol. 14, no. 3, pp. 262-270, 2011.

[7] A. Suryanti, "Upacara Adat Sedekah Laut di Pantai Cilacap," Sabda: Jurnal Kajian Kebudayaan (Journal of Cultural Analysis), vol. 3, no. 2, pp. 1-8, 2017. DOI: $10.14710 /$ sabda. $3.2 \% 25$ p.

[8] H. Hasan, "Pendidikan Sejarah Untuk Memperkuat PendidikanKarakter," Paramita, vol. 22, no. 1, pp. 81-95, 2012. DOI: 10.15293/paramita.v22i1.1875.

[9] A. Setiyawan, "Budaya Lokal Dalam Perspektif Agama: Legitimasi Hukum Adat ('Urf) Dalam Islam," Esensia, vol. 13, no. 2, pp. 203-222, 2012. DOI: 10.14421/esensia.v13i2.738.

[10] K. Saddhono and A. Kurniawan, "Islamic Religious Value in Traditional Ceremony of Begalan Banyumasan as Educational Character for Student at Senior High Schools In Central Java," J.UMRAN:International Journal of Islamic and Civilizational Studies, vol. 1, pp. 71-77, 2017. DOI: https://doi.org/10.11113/umran2017.4n1-1.206.

[11] L. Hadiningrum, "The Reactualization Of Value Education On Local Wisdom-Based (Cultural Study Of Langgam Syahadat Kures On The Tradition Of Sekaten In Surakarta)," Jurnal SmaRT, vol. 4, no. 2, pp. 149-159, 2018. DOI: 10.18784/smart.v4i2.652.

[12] J.W. Creswell, "Qualitative inquiry and research design: choosing among five tradition," London: SagePublication, 1998.

[13] J.P. Spradley, "Metode Etnografi,” Yogyakarta: Tiara Wacana, 2006.

[14] K. Saddhono, "Membangun Kearifan Lokal Melalui Karya Sastra Dan Budaya Daerah [Jawa]," Pros. Seminar Nasional Dan Budaya Institut Hundu Dharma Negeri Denpasar, pp. 8-17, 2017.

[15] F.N. Fatimah, E.T. Sulistyo and K. Saddhono, "Local Wisdom Value in Sayu Wiwit Folklore As The Revitalization of Behavioral Education" Karsa: Journal of Social and Islamic Culture, vol. 25, no. 1, pp. 179-199, 2017. DOI: 10.19105/karsa.v25i1.1118.

[16] A. Nugroho, "Developing Model of Entrepreneurship Culture Based on Acculturation of Socio-Religion Values and Local Cultural Wisdom," International Journal Advances in Social Science and Humanities, vol. 4, no. 04, pp. 11-20, 2016.

[17] A. Humaeni, "Ritual,Kepercayaan Lokal Dan Identitas Budaya Masyarakat Ciomas Banten," El-Harakah, vol. 17, no. 2, pp. 157-180, 2015. DOI: 10.18860/el.v17i2.3343.

[18] A.M Semi, “Anatomi sastra," Padang: Angkasa Raya, 1993.

[19] A. Wasilah, "Etnopedagogis," Bandung: Kiblat. 2009.

[20] A.R. Yunus, "Nilai-Nilai Islam Dalam Budaya Dan Kearifan Lokal (Konteks Budaya Bugis)," Jurnal Rihlah, vol. II, no. 1, pp. 1-12, 2015. DOI: 10.24252/rihlah.v2i01.1351.

[21] Endraswara, "Falsafah Hidup Jawa: Menggali Mutiara Kebijakan Dari Intisari Filsafat Kejawen," Yogyakarta: Cakrawala, 2013.

[22] S. Poespowardojo, "Strategi Kebudayaan Suatu Pendekatan Filosofis," Jakarta : Gramedia Pustaka Utama, 1993. 
[23] M. Alfan, "Filsafat Kebudayaan," Bandung: CV. Pustaka Setia, 2013.

[24] Hartoyo, "The Study of The Social Realities Of The Nyadran Tradition Among Fishing Communities," International Journal of Information Research and Review, vol. 04, no. 04, pp. 3994-4000, 2017.

[25] U. Nuha, "Tradisi Ritual Buka Luwur (Sebuah Media Nilai-nilai Islam dan Sosial Masyarakat Kudus)," Jurnal SmaRT, vol. 2, no. 1, pp. 55-65, 2016. DOI: 10.18784/smart.v2i01.g215. 